\title{
Effect of Organic and Inorganic Sources of Nutrients on Soil Chemical Properties and Nutrient Availabilities under Direct Seeded Rice in Inceptisols of Bastar Plateau Zone
}

\author{
Poornima Sahu, T. Chandrakar*, G. K. Sharma, A. K. Thakur and M. Paikra \\ SG College of Agriculture \& Research Station, Jagdalpur (Chhattisgarh)-494005, India \\ *Corresponding author
}

\begin{tabular}{l} 
Ke y w o r d s \\
$\begin{array}{l}\text { Organic and } \\
\text { inorganic sources, } \\
\text { Chemical properties } \\
\text { and nutrient } \\
\text { availability }\end{array}$ \\
\hline Article Info \\
$\begin{array}{l}\text { Accepted: } \\
\text { 18 April } 2020 \\
\text { Available Online: } \\
\text { 10 May } 2020\end{array}$ \\
\hline
\end{tabular}

A field experiment was carried out at S.G. College of Agriculture and Research Station, Jagdalpur, Chhattisgarh during Kharif 2016 to study the effect of organic and inorganic sources of nutrients on soil chemical properties and nutrient availabilities under direct seeded rice in Inceptisols of Bastar plateau zone. The experiment was conducted in randomized block design with twelve treatments and four replications. The $100 \%$ NPK i.e. recommended dose of fertilizers were 100:60:40 kg N: $\mathrm{P}_{2} \mathrm{O}_{5}: \mathrm{K}_{2} \mathrm{O}$ / ha for rice crop. Soil samples were collected from the top soil surface $(0-15 \mathrm{~cm})$ of all the four replications before and after Kharif 2016 and analyzed for chemical properties and nutrients availabilities. The highest $\mathrm{pH}$ (6.70) was recorded in $50 \% \mathrm{NPK}+5 \mathrm{t} \mathrm{FYM}+\mathrm{ZnSO}_{4} @ 25 \mathrm{~kg} / \mathrm{ha}+$ lime $3 \mathrm{q} / \mathrm{ha}\left(\mathrm{T}_{12}\right)$ whereas the lowest $\mathrm{pH}$ (6.1) was recorded in $100 \%$ NPK. A slight increase in soil $\mathrm{pH}$ was observed in all the treatments which received FYM and lime and decrease was recorded in treatments which received inorganic nutrient sources as compared to the initial. The continuous application of organic materials along with fertilizers significantly increased the soil organic carbon as compared to the application of fertilizers alone. The use of organic manure like FYM with chemical fertilizers increased the availability of macro ( $\mathrm{N}, \mathrm{P}, \mathrm{K}, \mathrm{S}, \mathrm{Ca}$, and $\mathrm{Mg}$ ) and micro (Zn) nutrients in soil over chemical fertilizer alone.

\section{Introduction}

Rice (Oryza sativa L.) occupies a pride place among the food crops cultivated in India which has the largest area among rice growing countries and stands second in the production. In India, during the past three decades, intensive agriculture involving high yielding varieties of rice has led to heavy withdrawal of nutrients from the soil.
Use of organic manures in present agriculture is decreasing day by day. Its utility has not only improved the physical, chemical and biological properties of soil but also maintained the good soil health.

Long-term experiment has shown that crop residues incorporation, farm yard manures and green manures increased soil +organic carbon and nutrient availability as compared 
to the nitrogenous fertilizers alone (Lado et al., 2004). The advantage of combining organic and inorganic sources of nutrients in integrated nutrient management has been proved superior to the use of each component separately (Palaniappan and Annadurai, 2007). The use of organics plays a major role in maintaining soil health due to buildup of soil organic matter, beneficial microbes. The conjunctive application of organics with inorganic sources of nutrient reduces the dependence on chemical inputs and it not only acts as a source of nutrient but also provides micronutrient as well as modifies the soil physical behaviour and increases the efficiency of applied nutrients (Pandey et al., 2007). Integrated application of inorganic fertilizers and organic manures with micronutrients helped in increasing the availability of nutrients and in sustaining and restoring soil fertility in its available nutrients and major physical and chemical characteristics of the soil. Utilization of indigenous organic sources, viz. farmyard manure (FYM), obnoxious weeds and green leaf manures may serve as alternatives or supplements to chemical fertilizers, and help in increasing the productivity of the ricebased cropping system in all zones of the country.

\section{Materials and Methods}

The field experiment was conducted in midland field under long term fertilizer experiment, AICRIP-Dryland Agriculture at SG College of Agriculture and Research Station, Kumhrawand, Jagdalpur (C.G.) during Kharif 2016. The experimental soils was sandy loam having $\mathrm{pH} 6.3$ and EC 0.02 $\mathrm{dSm}^{1}$, organic carbon status $0.56 \%, 186 \mathrm{~kg}$ ha $^{1}$ of alkaline $\mathrm{KMnO}_{4} \mathrm{~N}, 21.4 \mathrm{~kg} \mathrm{ha}^{-1} \mathrm{P}, 178$ $\mathrm{kg} \mathrm{ha}^{1}$ of $\mathrm{NH}_{4} \mathrm{OAC}-\mathrm{K}, 33 \mathrm{~kg} \mathrm{ha}^{1}$ of Turbidimetric- S, 92 and $58 \mathrm{~kg} \mathrm{ha}^{-1}$ of EDTA titrated- $\mathrm{Ca} \& \mathrm{Mg}$, respectively and $1.03 \mathrm{ppm}$ DTPA extractable zinc. The experiment was conducted with twelve treatments namely $\mathrm{T}_{1}$ (control), $\mathrm{T}_{2}(100 \%$ NPK i.e. 100:60:40 $\left.\mathrm{kg} / \mathrm{ha} \mathrm{N}: \mathrm{P}_{2} \mathrm{O}_{5}: \mathrm{K}_{2} \mathrm{O}\right), \mathrm{T}_{3}(100 \% \mathrm{PK}), \mathrm{T}_{4}(100 \%$ $\mathrm{NK}), \quad \mathrm{T}_{5}(100 \% \quad \mathrm{NP}), \quad \mathrm{T}_{6}(100 \% \quad \mathrm{NPK}+5 \quad \mathrm{t}$ FYM $), \quad \mathrm{T}_{7}(100 \% \quad \mathrm{NPK}+5 \quad \mathrm{t} \quad \mathrm{FYM}+$ $\left.\mathrm{ZnSO}_{4} @ 25 \mathrm{~kg} \quad \mathrm{ha}^{-1}\right), \quad \mathrm{T}_{8}(100 \% \quad \mathrm{NPK}+5 \quad \mathrm{t}$ FYM+ ZnSO $925 \mathrm{~kg} \mathrm{ha}^{-1}+$ Lime $\left.3 \mathrm{q} \mathrm{ha}^{-1}\right), \mathrm{T}_{9}$ (50\% NPK), $\mathrm{T}_{10}(50 \% \mathrm{NPK}+5 \mathrm{t}$ FYM $), \mathrm{T}_{11}$ $\left(50 \% \mathrm{NPK}+5 \mathrm{t} \mathrm{FYM}+\mathrm{ZnSO}_{4} @ 25 \mathrm{~kg}\right.$ $\left.\mathrm{ha}^{-1}\right)$ and $\mathrm{T}_{12}(50 \% \mathrm{NPK}+5 \mathrm{t}$ FYM+ $\mathrm{ZnSO}_{4} @ 25 \mathrm{~kg} \mathrm{ha}^{-1}+$ Lime $\left.3 \mathrm{q} \mathrm{ha}^{-1}\right)$. The experiment was laid out in randomized block design (RBD) with four replications. Soil samples were collected from the top soil surface $(0-15 \mathrm{~cm})$ of all the four replications before and after Kharif 2016 and analyzed for chemical properties and nutrients availabilities using standard procedures.

\section{Results and Discussion}

\section{pH}

The $\mathrm{pH}$ of the soil was statistically influenced by different treatments (Table 1). The $\mathrm{pH}$ of the soil ranged from 6.11 to 6.70 . The highest (6.70) value was recorded in $50 \% \mathrm{NPK}+5 \mathrm{t}$ $\mathrm{FYM}+\mathrm{ZnSO}_{4} @ 25 \mathrm{~kg} / \mathrm{ha}+$ lime 3 q/ha $\left(\mathrm{T}_{12}\right)$ whereas the lowest (6.1) value was recorded in $100 \%$ NPK. A slight increase in soil $\mathrm{pH}$ was observed in all the treatments as compared to the initial (6.59) soil $\mathrm{pH}$ studied during the starting of the experiment. This was ascribed to the neutralizing effect of lime in the field. This was supported by the findings of Parvathi et al., (2013).

\section{Organic carbon}

The continuous application of organic materials along with fertilizers significantly increased the soil organic carbon as compared to the application of fertilizers alone (Table $1)$. The highest $(0.83 \%)$ value was observed in $100 \% \mathrm{NPK}+5$ t FYM + $\mathrm{ZnSO}_{4} @ 25 \mathrm{~kg}$ / ha $\left(\mathrm{T}_{7}\right)$ followed $(0.82)$ by $\% \mathrm{NPK}+5 \mathrm{t} \mathrm{FYM}$ 
+ $\mathrm{ZnSO}_{4} @ 25 \mathrm{~kg} / \mathrm{ha}+\mathrm{Lime} 3 \mathrm{q} / \mathrm{ha}\left(\mathrm{T}_{8}\right)(0.82)$ where as the lowest $(0.52)$ was observed in $100 \%$ PK $\left(\mathrm{T}_{3}\right)$. Organic carbon plays an important role in maintaining soil health and its increase during the period of experimentation shows that use of fertilizers has contributed in improving the soil health. The highest value of organic content i.e. $0.83 \%$ in $100 \% \mathrm{NPK}+5 \mathrm{t} \mathrm{FYM}+\mathrm{ZnSO}_{4} @ 25$ $\mathrm{kg} / \mathrm{ha}$ treatment can be assigned to the annual use of FYM @ 5 ton ha ${ }^{-1}$ during the period of experimentation. This also indicates that if fertilizer use is integrated with manure, substantial improvement in soil health can be expected. The similar results were also found by Sharma and Sharma (2002), Kumar et al., (2001) and Antil et al., (2011).

\section{Available nitrogen}

The combine application of manure and fertilizer exhibited a significant effect on available nitrogen in the soil. The $100 \%$ NPK +5 t FYM $\left(\mathrm{T}_{6}\right)$ treated plot had significantly greater available Nitrogen $(264.2 \mathrm{~kg} / \mathrm{ha})$ followed by $100 \%$ NPK + 5 t FYM + $\mathrm{ZnSO}_{4} @ 25 \mathrm{~kg} / \mathrm{ha} \quad\left(\mathrm{T}_{7}\right)$ treated plot as compared to control and other treatments plots. The $100 \% \mathrm{NPK}+5 \mathrm{t} \mathrm{FYM}\left(\mathrm{T}_{6}\right)$ and $100 \% \mathrm{NPK}+5$ t FYM + $\mathrm{ZnSO}_{4} @ 25 \mathrm{~kg} / \mathrm{ha}$ $\left(\mathrm{T}_{7}\right)$ treatments registered $56.4 \%$ and $47.3 \%$ higher available nitrogen than the control. A perusal of the data (Table 1) revealed that available nitrogen varied from $150.1 \mathrm{~kg} / \mathrm{ha}$ under control $\left(\mathrm{T}_{1}\right)$ to $275.6 \mathrm{~kg} /$ ha under $100 \%$ $\mathrm{NPK}+5 \mathrm{t} \mathrm{FYM}\left(\mathrm{T}_{6}\right)$. Application of chemical fertilizers with organic manures increased available nitrogen over other treatments as well as control.

Application of 50 and $100 \%$ NPK ( $\left.\mathrm{T}_{9} \& \mathrm{~T}_{2}\right)$, $100 \% \mathrm{NP}\left(\mathrm{T}_{5}\right)$ and $100 \% \mathrm{NK}\left(\mathrm{T}_{4}\right)$ and $100 \%$ PK $\left(\mathrm{T}_{3}\right)$ significantly increased the available nitrogen content in soil over control. Similarly, incorporation of organic manures along with chemical fertilizers also increased available nitrogen content over control. The highest available nitrogen $\left(264.2 \mathrm{~kg} \mathrm{ha}^{-1}\right)$ was found in the plots which received $100 \%$ NPK $+5 \mathrm{t}$ FYM followed by $100 \%$ NPK $+5 \mathrm{t}$ $\mathrm{FYM}+\mathrm{ZnSO}_{4} @ 25 \mathrm{~kg} / \mathrm{ha}\left(\mathrm{T}_{7}\right)\left(248.8 \mathrm{Kg} \mathrm{ha}^{-1}\right)$. Amongst sources of nutrients, FYM with inorganics fertilizer proved best as compare to inorganics alone.

The lower available nitrogen in control plot $\left(168.9 \mathrm{~kg} \mathrm{ha}^{-1}\right)$ is a result of mining of available nitrogen with continuous cropping without fertilization over a long period of time. Increase in available nitrogen with organics is attributed to its direct addition through organics as FYM contained $264.2 \mathrm{~kg}$ $\mathrm{ha}^{-1}$ available nitrogen. The favorable soil conditions viz. organic carbon, porosity, water holding capacity etc. might have helped in the mineralization of soil nitrogen leading to buildup of higher available nitrogen. The results are in conformity with the findings of Singh et al., (2007) and Urkurkar et al., (2010).

\section{Available phosphorus}

The available phosphorus was significantly influenced by the fertilizer and organic manure applied over the cropping years. The $50 \% \mathrm{NPK}+5$ t FYM + ZnSO $@ 25 \mathrm{~kg} \mathrm{ha}^{-1}$ $\left(\mathrm{T}_{11}\right)$ recorded significantly higher available phosphorus as compared to its value in other treatments. Available Phosphorus content of soil was increased as compared to its initial status. The $100 \% \mathrm{NPK}+5 \mathrm{t} \mathrm{FYM}\left(\mathrm{T}_{6}\right)$ also recorded significantly higher available phosphorus than control and other treatments. The 50\% NPK + 5 t FYM + ZnSO $@ 25 \mathrm{~kg}$ $\mathrm{ha}^{-1}\left(\mathrm{~T}_{11}\right)$ and $100 \%$ NPK+ 5 t FYM $\left(\mathrm{T}_{6}\right)$ registered $118.6 \%$ and $107.4 \%$ higher available phosphorus than the control, respectively. The data given in table 1 revealed that the available phosphorus content of soil during Kharif 2016 varied from 9.4 to $31.3 \mathrm{~kg} \mathrm{ha}{ }^{-1}$ amongst different treatments. 
Graded doses of chemical fertilizers also increased the available phosphorus contents in soil over control. Among the plots treated with FYM, zinc sulphate, lime and RDF recorded highest available phosphorus content followed by FYM plus RDF.

The organic matter forms a cover on sesquioxides and makes them inactive and thus reduces the phosphate fixing capacity of the soil, which ultimately, helps in release of ample quantity of phosphorus. Similar result was found by Tolanur and Badanur (2003).

\section{Available potassium}

The available potassium was significantly affected by long-term application of inorganic fertilizer and manure. The available $\mathrm{K}$ in $100 \%$ NPK + 5 t FYM were significantly higher than other treatments. Fertilizer plus manure application (100\% NPK + 5 t FYM) increased available potassium by $43.5 \%$ followed by $100 \% \mathrm{NPK}+5 \mathrm{t} \mathrm{FYM} \mathrm{+} \mathrm{ZnSO}_{4}$ @ $25 \mathrm{~kg} / \mathrm{ha}+$ lime $3 \mathrm{q} / \mathrm{ha}\left(\mathrm{T}_{8}\right) 37.3 \%$ as compared to the control.

The data tabulated in Table 1 revealed that during Kharif 2016,available K content of soil varied from a minimum of $139.8 \mathrm{~kg} \mathrm{ha}^{-1}$ under control to a maximum of $214.2 \mathrm{~kg} \mathrm{ha}^{-1}$ under $100 \%$ NPK + FYM. Application of organic manures along with chemical fertilizers increased the available $\mathrm{K}$ content of soil significantly over control. Increase in available potassium due to addition of organic manures may be ascribed to the reduction of potassium fixation and release of potassium due to interaction of organic matter with clay, besides the direct potassium addition to the pool of soil (Urkurkar et al., 2010). Such increase in the content of available potassium with the use of organics with chemical fertilizers has also been reported by Singh $e t$ al., (2007).

\section{Available sulphur}

The data on available sulphur content in soil after harvest of rice crop was arranged in Table 1. The range of available sulphur was vary from 17.3 to $51.2 \mathrm{~kg} / \mathrm{ha}$ in various treatments. Highest available sulphur $45.7 \mathrm{~kg}$ $\mathrm{ha}^{-1}$ was obtained with $\mathrm{T}_{11}(50 \% \mathrm{NPK}+5 \mathrm{t}$ FYM+ $\mathrm{ZnSO}_{4} @ 25 \mathrm{~kg} \mathrm{ha}^{-1}$ ) followed by $\mathrm{T}_{12}$ $\left(50 \% \mathrm{NPK}+5\right.$ t FYM+ $\mathrm{ZnSO}_{4} @ 25 \mathrm{~kg} \mathrm{ha}^{-1}+$ Lime $\left.3 \mathrm{q} \mathrm{ha}^{-1}\right)\left(44.1 \mathrm{~kg} \mathrm{ha}^{-1}\right)$ and lowest (23.9 $\mathrm{kg} \mathrm{ha}^{-1}$ ) in control. Continuous use of organic and inorganic sources of nutrients since 201415 is conducive for maintaining the soil available sulphur. The results of the present study revealed that higher available sulphur content were recorded in integrated nutrient management treatments which were relatively half does of nutrient as compared to absolute inorganics and control.

\section{Available calcium}

The available calcium was not significantly influenced by the fertilizer and organic manure applied over the cropping years. The $100 \%$ NPK + 5 t FYM treatment recorded higher (94.5 kg/ha) available calcium as compared to its value in other treatments.

The $100 \%$ NPK + 5 t FYM(T 6 and $50 \%$ NPK

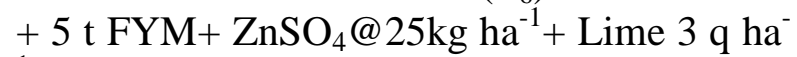
${ }^{1}\left(\mathrm{~T}_{12}\right)$ treatments registered $4.21 \%$ and $3.74 \%$ higher available calcium than the control. The data given in table 1 revealed that the available calcium content of soil during Kharif 2016 varied from 88.4 to $96.2 \mathrm{~kg} \mathrm{ha}^{-}$ 1 amongst different treatments.

Graded doses of chemical fertilizers also increased the available calcium contents in soil over control. Among the plots treated with FYM, zinc sulphate, lime and RDF recorded highest available calcium content followed by FYM plus RDF. Similar result was found by Chukwu et al., (2012). 
Table.1 Effect of organic and inorganic sources of nutrients on soil properties after Kharif rice harvest

\begin{tabular}{|c|c|c|c|c|c|c|c|c|c|}
\hline Treatment & pH & $\begin{array}{c}\text { OC } \\
\%\end{array}$ & $\begin{array}{l}\text { Available } \\
\mathbf{N}(\mathbf{k g} / \mathrm{ha})\end{array}$ & $\begin{array}{c}\text { Available } \\
\mathrm{P}_{2} \mathrm{O}_{5}(\mathrm{~kg} / \mathrm{ha})\end{array}$ & $\begin{array}{c}\text { Available } \\
\mathrm{K}_{2} \mathrm{O}(\mathrm{kg} / \mathrm{ha})\end{array}$ & $\begin{array}{l}\text { Available } \\
\text { S (kg/ha) }\end{array}$ & $\begin{array}{l}\text { Available } \\
\text { Ca (kg/ha) }\end{array}$ & $\begin{array}{l}\text { Available } \\
\text { Mg (kg/ha) }\end{array}$ & $\begin{array}{l}\text { Available } \\
\text { Zn (ppm) }\end{array}$ \\
\hline Control & 6.28 & 0.57 & 168.9 & 13.4 & 145.6 & 23.9 & 90.7 & 57.3 & 1.00 \\
\hline $100 \%$ NPK & 6.11 & 0.75 & 200.5 & 22 & 174.7 & 30.7 & 92.2 & 55.3 & 0.98 \\
\hline $100 \% \mathrm{PK}$ & 6.33 & 0.52 & 159.0 & 26.8 & 194.5 & 28.6 & 91.0 & 55.9 & 0.99 \\
\hline $100 \% \mathrm{NK}$ & 6.19 & 0.57 & 197.7 & 16.0 & 190.4 & 23.6 & 91.4 & 55.5 & 0.98 \\
\hline $100 \% \mathrm{NP}$ & 6.26 & 0.57 & 214.6 & 24.9 & 140 & 26.0 & 89.7 & 54.8 & 0.98 \\
\hline $100 \%$ NPK+5 t FYM & 6.44 & 0.82 & 264.2 & 27.8 & 209 & 35.4 & 94.5 & 58.4 & 1.04 \\
\hline $\begin{array}{l}\text { 100\% NPK+5 t FYM+ } \\
\mathrm{ZnSO}_{4} @ 25 \mathrm{~kg} \mathrm{ha}^{-1}\end{array}$ & 6.46 & 0.86 & 248.8 & 24.6 & 200 & 41.7 & 93.8 & 58.8 & 1.09 \\
\hline $\begin{array}{l}\text { 100\% NPK+5 t FYM+ ZnSO } @ 25 \mathrm{~kg} \\
\mathrm{ha}^{-1}+\text { Lime 3q ha }\end{array}$ & 6.62 & 0.87 & 229.9 & 26.7 & 189.8 & 37.9 & 94.3 & 58.8 & 1.10 \\
\hline $50 \%$ NPK & 6.19 & 0.71 & 189.3 & 19.6 & 162.6 & 32.8 & 90.0 & 56.6 & 0.99 \\
\hline $50 \%$ NPK + 5 t FYM & 6.45 & 0.76 & 233.3 & 25.5 & 196.3 & 41.3 & 93.2 & 58.5 & 1.04 \\
\hline $\begin{array}{l}50 \% \mathrm{NPK}+5 \mathrm{t} \text { FYM+ ZnSO } \\
\text { ha }^{-1}\end{array}$ & 6.51 & 0.81 & 231.8 & 29.3 & 190.4 & 45.7 & 92.8 & 59.2 & 1.10 \\
\hline $\begin{array}{l}50 \% \mathrm{NPK}+5 \text { t FYM+ ZnSO } \\
\text { ha }^{-1}+\text { Lime } 3 \text { q ha }^{-1}\end{array}$ & 6.70 & 0.84 & 242.6 & 26.0 & 189.3 & 44.1 & 94.1 & 59.3 & 1.10 \\
\hline $\mathrm{CV} \%$ & 1.11 & 7.75 & 5.3 & 12.0 & 4.0 & 14.6 & 1.5 & 2.5 & 2.86 \\
\hline CD $(5 \%)$ & 0.10 & 0.08 & 16.5 & 4.0 & 10.5 & 7.2 & 2.0 & 2.0 & 0.04 \\
\hline CD $(1 \%)$ & 0.13 & 0.10 & 22.2 & 5.4 & 14.1 & 9.7 & 2.7 & 2.8 & \\
\hline
\end{tabular}




\section{Available magnesium}

The data on available $\mathrm{Mg}$ content in soil after harvest of rice crop was arranged in Table 1. The range of available $\mathrm{Mg}$ was vary from 53 to $61.2 \mathrm{~kg} / \mathrm{ha}$ in various treatments.

Highest available $\mathrm{Mg} 59.3 \mathrm{~kg} \mathrm{ha}{ }^{-1}$ was obtained with $\mathrm{T}_{12}(50 \% \mathrm{NPK}+5 \mathrm{t}$ FYM+ $\mathrm{ZnSO}_{4} @ 25 \mathrm{~kg} \mathrm{ha}^{-1}+$ Lime $3 \mathrm{q} \mathrm{ha}^{-1}$ ) followed by $\left(59.2 \mathrm{~kg} \mathrm{ha}^{-1}\right) \mathrm{T}_{11}(50 \% \mathrm{NPK}+5 \mathrm{t} \mathrm{FYM+}$ $\mathrm{ZnSO}_{4} @ 25 \mathrm{~kg} \mathrm{ha}^{-1}$ ) treatment and lowest $\left(57.3 \mathrm{~kg} \mathrm{ha}^{-1}\right)$ in control.

Continuous use of balanced fertilizer i.e. organic and inorganic since 2014-15 is conducive for maintaining the soil available $\mathrm{Mg}$. The results of the present study revealed that higher available $\mathrm{Mg}$ content were recorded in integrated nutrient management treatments which was relatively half does of nutrient as compared to absolute inorganics and control. Similar result was found by Hemalatha and Chellamuthu (2013).

\section{DTPA extractable zinc}

The DTPA extractable zinc was not significantly influenced by the fertilizer and organic manure applied over the cropping years. The treatment $\mathrm{T}_{8}(100 \% \quad \mathrm{NPK}+5 \quad \mathrm{t}$ $\mathrm{FYM}+\mathrm{ZnSO}_{4} @ 25 \mathrm{~kg} \mathrm{ha}^{-1}+$ Lime $3 \mathrm{q} \mathrm{ha}^{-1}$ ), $\mathrm{T}_{11}\left(50 \% \mathrm{NPK}+5 \mathrm{t} \mathrm{FYM}+\mathrm{ZnSO}_{4} @ 25 \mathrm{~kg}\right.$ ha $\left.{ }^{1}\right)$ and $\mathrm{T}_{12}(50 \% \mathrm{NPK}+5 \mathrm{t} \mathrm{FYM}+$ $\mathrm{ZnSO}_{4} @ 25 \mathrm{~kg} \mathrm{ha}^{-1}+$ Lime $3 \mathrm{q} \mathrm{ha}^{-1}$ ) were recorded the highest $(1.10 \mathrm{ppm})$ availability of zinc. Followed by treatment $100 \%$ NPK +5 t FYM + $\mathrm{ZnSO}_{4} @ 25 \mathrm{~kg} / \mathrm{ha}(1.09$ ppm).

The combine use of RDF, FYM, lime, and zinc sulphate increase the availability of zinc in the soil as compare to RDF alone. Even though half does of RDF also increased the zinc availability when that is applied with organics nutrient. Similar result was found by Vidyavathi (2012).
Continuous application of chemical fertilizers with integration of the organics influence $\mathrm{pH}$ of soil significantly. However, the organic carbon content was higher in $100 \% \mathrm{NPK}+5 \mathrm{t}$ FYM+ ZnSO ${ }_{4} @ 25 \mathrm{~kg} \mathrm{ha}^{-1}$ treatments. The inorganic fertilizer and organic manure maintained and/or sustained highest levels of available $\mathrm{N}, \mathrm{P}, \mathrm{K}, \mathrm{S}, \mathrm{Ca}, \mathrm{Mg}$, and $\mathrm{Zn}$ due to its long-term application. Higher response was observed in integrated use of organic along with inorganic fertilizer for the nutrient supply of rice crop and further it improves the organic carbon and available nitrogen and potassium content of soil.

\section{References}

Antil, R.S., Narwal, R.P., Singh, B and Singh, J.P. 2011. Long- term effects of FYM and $\mathrm{N}$ on soil health and crop productivity under pearl millet - wheat cropping system. Ind. J. Fert. 7: 14-32.

Chukwu, L.I., Ano, A.O. and Asawalam, D.O. 2012. Effects of Poultry Manure and NPK fertilizer on soil properties and Nutrient uptake of maize (Zea mays L.) plants growth in an ultisol. Proceedings of the 36th Annual Conference of the Soil Science Society of Nigeria (SSSN) on 7th - 11th March, 2012 University of Nigeria Nsukka.

Kumar, N., Verma, L.P., Singh, Room and Prasad, K. 2001. Soil Properties, nutrient uptake and productivity of rice under integrated nutrient management system. Ann. plant Soil Res. 3(1): 112 115.

Palaniappan, S.P. and Annadurai, K. 2007. Organic Farming: Theory and Practices, 169. Scientific Publishers, Jodhpur.

Pandey, N., Verma, A.K., Anurag, Tripathi, R.S. 2007. Integrated nutrient management in transplanted hybrid rice (oryza sativa). Indian J. Agron. 52(1): 40-42. 
Sharma, S.K. and Sharma, S.N. 2002. Integrated nutrient management for sustainability of rice (Oryza sativa) Wheat (Triticum aestivum) cropping system on soil fertility. Indian J. Agril. Sci. 70(6): 357-359.

Singh, K.P., Srivastava, T.K., Singh, P.N. and Archana Suman. 2007. Enhancing Soil fertility, microbial activity and Sugarcane (Saccharum Officinarum) productivity through organics in subtropical conditions. The Indian J. Agril. Sci. 77(2): 84-87.

Tolanur, S.I and Badanur, V.P., 2003. Effect of integrated use of organic manure, green manure and fertilizer nitrogen on sustaining productivity of Rabi sorghum
- chickpea system and fertility of a vertisol. J. Indian Soc. Soil Sci., 51: 4145.

Urkurkar, J.S., Tiwari, A., Shrikanth Chitale and Bajpai, R.K. 2010. Influence of long term use of inorganic and organic manures on soil fertility and sustainable productivity of rice (Oryza sativa) and Wheat (Triticum aestivum) in Inceptisols. Indian J. Agril. Sci., 80. (3): 208-212.

Vidyavathi, G. S., Dasog, H. B., Babalad, N. S., Hebsur, S. K., Gali, S. G., Patil And Alagawadi, A. R. 2012. Nutrient Status Of Soil Under Different Nutrient And Crop Management Practices. Karnataka J. Agril. Sci., 25 (2): 193-198.

\section{How to cite this article:}

Poornima Sahu, T. Chandrakar, G. K. Sharma, A. K. Thakur and Paikra, M. 2020. Effect of Organic and Inorganic Sources of Nutrients on Soil Chemical Properties and Nutrient Availabilities under Direct Seeded Rice in Inceptisols of Bastar Plateau Zone. Int.J.Curr.Microbiol.App.Sci. 9(05): 2592-2598. doi: https://doi.org/10.20546/ijcmas.2020.905.296 